\title{
Form and Diversity in American Crime Fiction: The Southern Forensic Thriller
}

\begin{abstract}
The forensic thriller has traditionally been constructed as a mainstream American narrative focused on the stereotypical representation of the country as a metropolis with an incredible amount of resources, and the American capitalist dream. The author Patricia Cornwell (Postmortem, first novel in the Kay Scarpetta series, published in 1990) is considered the founding mother of this crime fiction subgenre native to the US, closely followed by Kathy Reichs (Dèja Dead, first novel in the Temperance Brennan series, published in 1997) whose series have been successfully adapted to television in the show Bones (2005-2017). But the $21^{\text {st }}$ century has seen the inclusion of more diverse settings for these stories, the South being the most economically successful and dominated by women authors too. Georgian Karin Slaughter is the author of the "Grant County" series, set in the fictional town of Heartsdale, in rural Georgia, and responsible for the inscription of the South in American forensic thrillers thanks to her own experience as a native. Blindsighted (2001) includes elements from both the grotesque southern gothic and the hard boiled tradition. My analysis of the first novel in the series will examine how the southern environment becomes quintessential to the development of the crimes and the characters from a literary, philosophical and feminist point of view. The issues examined will include, but not be limited to crime, morals, religion, professional ambition, infidelity, divorce, sexual desire, infertility, and family relationships.
\end{abstract}

Keywords: Literature, crime fiction, southern, forensics, thriller

\section{The Forensic Thriller}

The forensic thriller is the name given to a series of crime novels produced from 1990 onwards in the US that share a series of characteristics, the first and most important being the featuring of forensic science in the solving of murder cases and the final restoration of the status quo. Critics and academics alike agree in considering Postmortem by Patricia Cornwell, published in 1990, the first forensic thriller as it marks the start of a new literary tradition that has shaped not only crime fiction literary productions but television shows in the $21^{\text {st }}$ century. Cornwell's success inspired a generation of writers to challenge the conventions of crime narratives based solely on the detective's ability to solve a crime thanks to logical thinking. The evolution of the forensic thriller in the US is therefore linked to the evolution of science and technology in the last decades of the $20^{\text {th }}$ century and it is tightly linked to the appearance of new forms of investigation.

In 1997, forensic anthropologist Kathy Reichs published the first novel in the Temperance Brennan series inspired by her own real-life work as an internationally renowned forensic anthropologist. The series is responsible for introducing the liminal field of forensic anthropology into mainstream cultural productions and challenging the way scientific knowledge is represented and absorbed by the general public by inscribing the personal experience of the author in the text (Cohen 249). After the success of the Scarpetta and Brennan series, more scientific professionals with an interest in writing 
saw their works published, with their own real-life experiences used as marketing strategies to highlight the hyper-realism of their works. Another author with a scientific background who has enjoyed moderate success in the US is Tess Gerritsen. After writing medical thrillers during the 1990's, she finally created the Rizzoli \& Isles series in 2001 featuring Boston Police Department detective Jane Rizzoli and forensic doctor Maura Isles (Gerritsen The Sinner, The Apprentice, The Surgeon).

The emergence of the forensic thriller is closely tied to the US crime fiction tradition as it borrows iconic elements from the hard boiled tradition. These elements affect the way the hero is portrayed, but also the detecting methods used to solve the crime (Walton and Jones). The portrayal of the hero/heroine in forensic thrillers - as an individual who fights against a corrupt system - is maintained, though ironically the forensic doctors of these stories see themselves fighting against injustices happening in their own privileged and institutionalized environments. That is, these detectives are part of laboratories or institutions that do not meet their moral expectations but from which they get an almost unlimited resources that will help them solve the crime (Knight). In their fight against said injustices, the featuring of firearms as a source of self-defense is still present, with Scarpetta being a convinced gun-owner (Cornwell) and Brennan wishing for a gun when she is attacked in her own house (Reichs). However, the feature from the hard boiled tradition that has been maintained yet adapted to this new detecting paradigm is the appearance of specific linguistic codes. In the original hard boiled tradition, language specificity came from the detective's experience in the streets with an informal and high coded language. But in forensic thrillers, this specificity has been replaced by scientific language (Avanzas Álvarez 2018). Historically unavailable to non-experts, this language now floods the pages of forensic thrillers with the characters functioning as interpreters that help readers - and later on audiences - understand the consequences of these scientific developments for crime detection. See the following experiment carried out by doctor Brennan:

The blood knows its own proteins, or antigens. If it recognizes foreigners, antigens that don't belong, it tries to destroy them with antibodies. Some antibodies blow up foreign antigens, others clump them together. That clumping is called an agglutination reaction.

Antiserum is created in an animal, usually a rabbit or a chicken, by injecting it with the blood of another species. The animal's blood recognizes the invaders and produces antibodies to protect itself. Injecting an animal with human blood produces human antiserum. Injecting it with goat blood produces goat antiserum. Horse blood produces horse antiserum.

Human antiserum creates an agglutination reaction when mixed with human blood. Watch. If this is human blood a visible precipitate will form in the test tube, right where the simple solution and the antiserum meet. We'll compare the saline as control. (Reichs 429)

Though the excerpt quoted is full of technical words and describes a complex process, it is made available to general audiences through Brennan's description and explanation of its consequences for the crime she is investigating. From a cultural point of view, this narrative technique signals the appearance of a new paradigm in which science is no longer reserved only for an educated elite but becomes part of mainstream discourses. 
That is, readers and viewers can learn science from these cultural products, and they can incorporate this knowledge in their everyday lives and experiences.

With these innovations, the forensic thriller - due to its historical circumstances - offers readers more diversity than their original hard boiled antecessors, as the social and scientific developments of the late $20^{\text {th }}$ century allowed for social and scientific changes in the forms of representation of the story's traditional elements. So, by the end of the $20^{\text {th }}$ century, forensic thrillers were clearly an important part of US popular culture, and the portrayal of forensic science was at its peak with the release of the iconic television show CSI (2000-2015) in 2000. However, it must be noted that despite the success of these stories, they perpetuated one of the most relevant aspects of the hard boiled tradition by locating the stories in big cities where resources are not particularly scarce, and the diverse landscape offers readers a portrayal of the quintessential American city.

But the US is a large country with very different locations and cultures that have not historically found space in mainstream representation except in stereotyped images (the tough West, the conservative and boring Mid-West, the conservative and uncultured South, etc.). So, motivated by this lack of diversity in representation and looking to inscribe misrepresented US locations and cultures in popular products, a new type of forensic thriller appeared with the new millennium. The broad acceptance of science as the only way to produce truth (Foucault) has created a new global paradigm that no longer limits itself to big cities but has become the dominant discourse for crime-solving. Hence, the regional forensic thriller was born.

The aim of this paper is to analyze the main characteristics of the regional forensic thriller as an American text that plays a key role in inscribing the country's cultural diversity in mainstream literature, moving the historically preferred city landscapes to regions that have been misrepresented in popular culture products. The analysis will be complemented with a case of study of Karin Slaughter's Blindisghted (2001), the first novel in the "Grant County" series. Karin Slaughter's novels signify the diversity in forensic thrillers by moving the story from big cities to a small town in the state of Georgia, where the specificity of southern living, religion and the acclaimed Southern Gothic tradition enrich the narrative. The "Grant County" series, featuring pediatrician and coroner doctor Sara Linton and her ex-husband, Chief of Police Jeffrey Tolliver, relocates the detecting process to a small community where the main character no longer has access to the unlimited scientific resources of the big city. Even though Sara does not occupy a politically relevant post in her daily life like Scarpetta and Brennan - who were presented as internationally celebrated forensics experts - her role as the only pediatrician and coroner makes of her a respected figure in her native town of Heartsdale. Her authority is therefore rooted in her tight links to the community in small-town America challenging hard boiled conventions and signaling the importance of societal links for professionals and crime solving in the $21^{\text {st }}$ century.

\section{The Regional Forensic Thriller: Blindsighted (2001)}

In the first reference to the regional forensic thriller in crime fiction studies it appeared as a crime fiction subgenre in 2001, when authors Willem Johannes Bertens and Theo 
D'haen, motivated by their economic success, dedicated a whole chapter of their book Contemporary American Crime Fiction to this kind of book. One of the points that the authors make very early on their text is that regional forensic thrillers are predominantly written by women (Bertens and D'haen 60). Even though US crime fiction has been known for its celebrated male authors (Raymond Chandler, James Ellroy, Michael Connelly), it is women who have inscribed the country's diversity in mainstream novels. This is a feature that the regional forensic thriller shares with the general forensic thriller, whose main representatives (Cornwell, Reichs, and Gerritsen) have never hidden their identities behind pseudonyms or initials.

Though the regional forensic thriller can be located in any of the liminal regions of the US, the South has clearly emerged as the one preferred by readers if we use economic success as a measure. Women authors of southern forensic thrillers have taken advantage of the specificity that has characterized this crime fiction subgenre from its beginnings, and they have turned it into a tool to challenge the misconceptions about the South and southern culture. If their antecessors were required to be wellversed in forensic science to offer a better portrayal of the discipline in the forensic thriller, it is of the utmost necessity that southern forensic writers know about the codes that structure southern living in order to break away from stereotypical representations: "she must have intimate knowledge of the region in question and she must be able to conjure up a convincing representation by means of judiciously selected atmospheric detail, regional idiom, and scenic description" (Bertens and D'haen 68).

Part of this intrinsic knowledge comes from the author's own experience in a location that has been traditionally misrepresented, and which has gone through a severe economic crisis that has shaped not only their lives but local history and the landscape too. In Karin Slaughter's Blindsighted (2001) the native Georgian author highlights the local history of the fictional town of Heartsdale paying special attention to how politics have shaped the lack of resources:

\footnotetext{
'Grant County' was named for the good Grant, not Ulysses, but Lemuel Pratt Grant, a railroad builder who in the mid-1800s extended the Atlanta line deep into South Georgia and to the sea ... This rail line had put cities like Heartsdale, Madison, and Avondale in the map ... During the Depression, the citizens of Avondale, Heartsdale, and Madison decided to combine their police and fire departments as well as their schools ... [which] helped to keep the Grant line open; the county was much larger as a whole than as individual cities.

For nearly sixty years, the county prospered, until base closings, consolidations, and Reaganomics trickled down, crushing the economies of Madison and Avondale within three years of each other. (Slaughter 14-15)
}

Due to the uniqueness of the setting and the traditional misrepresentation of the South in mainstream US products, the representation of the environment can sometimes be more important than the solving of the crime (Bertens and D'haen 68). Though the research quoted above took place in 2001, the $21^{\text {st }}$ century has granted regional forensic thrillers a place in mainstream culture. A tendency to offer better and more complex representations of the South can be appreciated in recent cultural products such as Gillian Flynn's novel Sharp Objects (2007) and television shows in which 
the landscape sets the tone of the story, infusing it with a unique personality. Take for example Louisiana's distinctive landscape in True Detective's first season (2014) which has been described as "moody" and "atmospheric" (Denise) and is certainly unique.

One of the features that has characterized the South as a unique place comes from its public exposure to religion and religious symbols, as well as the influence of deeply religious beliefs in societal expectations. Even though the South has its own combination of religious practices in which Voodoo and Catholicism are also present, the dominant discourse is imposed by Evangelic Protestantism is what is known as the "Bible Belt," an area comprising most of the southern-eastern states. Though the naming of this area is informal, its creation has been derived from polls and census data that evaluated variables such as church attendance and the impact of Evangelic Protestantism on everyday life and culture. Georgia is at the heart of this area, and religious values structure life in Heartsdale, both spiritually and physically: "Contraceptives were still kept behind the counter" (Slaughter 211) and "Bookmarks with religious sayings were alongside diabetes bracelets" (Slaughter 213). Though these representations have been considered problematic in portrayals of the South from outsiders, Slaughter's take on the situation through Sara's eyes shows her ambivalence and her acceptance of religious influence as long as it does not compromise the town's safety. Only when the local chemist is found to be the serial killer twisting excerpts from the Bible to justify his actions, do Slaughter and her heroine condone religion.

Slaughter's efforts to fight unbalanced representations of the South also touch on two bones of contention in contemporary US culture: racism and the Ku Klux Klan's prevalent influence in contemporary politics. Closely interlinked, these two national traumas are still part of southern culture, and their importance as national scars in US history has become even more relevant during the Trump administration. Slaughter's ambivalence towards religion is not present when representing these two characteristics, and Blindsighted includes two male detectives in their fifties whose attitude towards women and non-white people is representative of a broken and traumatized South that still keeps up the KKK's "good work" (Slaughter 97). Their political views plague their appearance in the novel and when investigating the town's serial killer, they quickly become suspicious of "Pete's colored man" (Slaughter 108), who eventually gets attacked by fellow local KKK sympathizers only to be saved by the Chief of Police. These two men yearn for a time when strict gender roles structured life and they are also resentful of detective Lena Adams: "Frank wasn't thrilled to have women on the force ... He was constantly leaving Lena out of investigations ... He was not the kind of guy who would let his female partner lead an interrogation" (Slaughter 27). Taking a stance on these issues, Slaughter criticizes these political views through the attitudes of other characters towards these two men, though their appearance clearly signals the prevalence of these views in some southerners.

As it could not be otherwise in the US crime fiction tradition, the owning and using of firearms is also present in these novels. Sara, the main character in the "Grant County" series, secretly keeps a gun with her, and though Slaughter does not explicitly make Sara pro-guns, she uses the character's traumatic sexual assault to make a point about firearm ownership: "Sara certainly wasn't against private citizens having 
weapons, but he [Jeffrey] knew for a fact that she wasn't exactly comfortable around guns, especially the kind that could shoot the lock off a barn door" (Slaughter, 208). Her ownership of a gun is finally justified when she is proved to be the real target of the serial killer, a man who holds Sara responsible for the death of his sister during one of the doctor's shifts during her internship in Atlanta. By putting the main character in danger, Slaughter is playing on the character's fear and need for protection, and though it is Jeffrey who eventually saves her, the final confirmation of her fears become an emotional mechanism that justifies owning a gun.

Conservative values are then present in the novel, and they are also portrayed in the prevalence of the nuclear family. Regional forensic thrillers do not portray their hero as a lone wolf, but rather inscribe her in the community she was brought up in and still lives in. A central figure in this community is the mother, traditionally absent from US crime fiction (Munt), especially in those texts authored by men: it is unlike "its male counterpart in which the mother only rarely appears and is usually dead if she really is a presence (as in James Ellroy)" (Bertens and D'haen 60). For Sara Linton, her mother is a source of love, support and inspiration, and though they may differ in the little things, she knows that she can always count on her mother for comfort: "She had forgotten how good it felt to be comforted by her mother" (Slaughter 300).

However, that mother is rarely a lonely presence, and the hero finds herself surrounded by a network of support in the form of parents, siblings, and even expartners. Sara's father is also a source of support, both economically and emotionally. When Sara returned to Hearstdale after her sexual assault, she found a home in one of her father's apartments, and he offered her a new job to start fresh though she refused it. Breaking with sexist expectations for her daughters, Linton was happy to share his business with his two daughters and aptly renamed it "Linton and Daughters" (Slaughter 7) so that they felt included in the business. Though Sara chose to remain a doctor, her younger sister joined the family business. Sara has a loving relationship with Tessa despite their different lifestyles, as two quotations illustrate: "'I'm not like you. I can't just sleep around.' Tessa didn't take offence at this. Sara had not expected her to" and "Sara, you'll never understand that sex is different for some people. Sometimes it's just fucking" (Slaughter 78-80).

The appearance of these characters helps challenge traditional representations of the detective/doctor as a lonely hero who does not have any ties and has problems bonding with other human beings and establishing lasting and meaningful social connections. In fact, Sara had a nice childhood surrounded by as many privileges as her parents could afford, including her passion for school and studying: "When Sara became obsessed with school, a study with a half-bath was built into the attic" (Slaughter 80). Hence, one of the consequences of this blurring of the lines between the professional and the private is the consideration of crime as a moral problem that is not separate from everyday life but rather is an intrinsic part of it: "In a number of recent books, however, the personal and the professional ... do not simply exist side by side, as is usually the case, but gradually become entangled with each other, leading to often fundamental confrontations and insights. The case becomes a catalyst for personal growth" (Bertens and D'haen 62). This personal growth is related not only to the solving of the crime but also a to a more complex personal development of 
the main character. If Kay Scarpetta was a lone wolf, her identity was far more static during the first instalments of the series than Sara's own journey in Blindsighted which includes a personal trauma, sexual violence, and the misunderstanding of traditional southern values.

An important part of this growth is the construction of the hero as a complex human being rather than just a symbol representing moral order. Though another forensic thriller writer, Kathy Reichs, had already inscribed their heroine's sexual desire in the Temperance Brennan series (1997), this discourse is even more important in southern narratives as the presence of religion and conservative values had traditionally subjugated women's sexuality. However, Slaughter creates a main character who is well-aware of her desire and even exhibits it in inappropriate places, such as church:

She was actually fidgeting in her seat, thinking about Jeffrey touching her, the way his hands felt on her skin when Cathy Linton jabbed her elbow into Sara's ribs ... Cathy had crossed her arms angrily, her posture indicating she was resigning herself to the fact that Sara would go to hell for thinking about sex at the Primitive Baptist on Easter Sunday. (Slaughter 9)

Here not only is Sara experiencing desire in a holy place, but she is experiencing desire for her ex-husband, whom she divorced after he cheated on her with a local woman. Her struggle with her attraction for Jeffrey is present throughout the novel and it is made even more relevant as their love and their sexual history is deeply affected by Sara's sexual assault, which happened before their marriage and which she decided to keep from her husband.

The regional forensic thriller then moves along a thin line between tradition and innovation, and this tension is present not only in the culture and the lives of the characters but in the detecting methods used to solve the crime too. Sara is the town's coroner and pediatrician, a double responsibility motivated by her ambition "There were only so many sore throats and earaches Sara could take before her mind started to go numb" (Slaughter 80) - and influenced by the traumatic sexual assault that prevented her from pursuing a bigger and better career in Atlanta. Hence the use of up-to-date medical terms that characterized previous forensic thrillers is maintained in Blindsighted, and their use helps the plot move forward and, eventually solve the crime. Though technical in nature, these terms are made clear for non-expert readers so that they understand what is going on without going into too much detail:

Sara held her breath as she jabbed the three-inch needle into the woman's jugular. The needle called an introducer, would act as a funnel for three separate IV ports ... Sara rattled off the tests as she flushed the ports with heparin solution to keep them from clotting. 'Blood gases, tox screen, LFT, CBC, chem twenty-seven. Go ahead and pull for a coag panel while you're at it.' Sara paused. 'Dip her urine stat. I want to know what's going on before I do anything else.' (Slaughter 182)

This quote shows the appearance of technical and jargon terms such as "tox" which is short for "toxicology" and "coag" which is short for "coagulation." Though the author 
does not use Sara's expertise to explain these terms to the reader, their fatal results are made clear when the patient eventually dies.

Despite the tension that evolves with the crime narrative, the final restoration of the status quo that characterizes crime fiction always has a conservative resolution in regional forensic thrillers: "The regionalism that in the course of the last 15 years has become an important presence in crime fiction is almost always conservative. It ... wants to preserve a status quo that is threatened by current [events]" (Bertens and D'haen 74). Though conservative narratives involving racism and misogyny are being reconsidered in these stories, there are still traces of classism and social hierarchies in which race plays a key role. Detective Lena Adams - whose own Hispanic origins present themselves as a problem to her southern identity - even indulges in racism and classism using traditional southern rhetoric:

\begin{abstract}
She felt a bump on her arm and looked up in time to see Websters definition of a hick sitting down beside her. His face was sunburned from his neck to about an inch from his hairline where he had obviously been working outside wearing a baseball hat. His shirt was starched within an inch of its life, and the cuffs were tight around his thick wrists. (Slaughter 60)
\end{abstract}

Not only that but Lena, who is the first victim's twin sister, struggles throughout the novel with her sister's sexuality, and never acknowledges the relationship and the feelings that her beloved sister had for her long-time girlfriend, the town's librarian. The novel is plagued with her resentment, and she even tries to conceal her sister's sexual identity: "Now the whole world would know her sister was gay" (Slaughter, 96).

Despite the complex relationship that readers can have with these characteristics of southern living, Slaughter clearly portrays them as the norm, hence challenging mainstream representations of the South as an Other (Said 1978). One of the most representative challenges of that norm comes from the clash between northern and southern accents. In US culture, the southern accent is usually considered "sweet" and "sugar-coated" due to its unique vowel system. However, for Sara and Jeffrey their way of talking does not imply that "they have an accent," but northerners do:

Jeffrey's biggest problem with Moon ... was the language barrier. Moon was from somewhere up east, the kind of place where consonants took on a life of their own ... Her nasal tone and the fact that she spoke sixty miles an hour gave Jeffrey the impression that he was talking to a French horn. (Slaughter 320)

The South's uniqueness is reproduced on the page by incorporating elements from the celebrated southern Gothic tradition. The features of this literary movement perfectly fit the crime narrative as they highlight the extreme realism that has characterized forensic thrillers, allowing for gruesome and very detailed descriptions of crime scenes and dead bodies (Downey 2016). Though the forensic thriller is, in fact, responsible for a better and more responsible representation of dead bodies and forensic medicine, the regional forensic thriller set in the South takes this representation a step further. 
Darkness, violence and blood flood the crime scenes, and Slaughter does not shy away from the realistic representations that are now iconic of her writing.

She had been stabbed in the abdomen. Blood filled the toilet between her legs, dripping onto the tiled floor ... Sybil's shirt was pulled up, and Sara could see a large vertical cut down her abdomen, bisecting her navel and stopping at the pubic bone. Another cut, much deeper, slashed horizontally under her breasts ... Sara put her hand to the wound, trying to halt the bleeding, but blood seeped between her fingers as if she were squeezing a sponge. (Slaughter 12)

The excerpt quoted above describes the first crime scene, where Sara tries to save Lena's sister to no avail. Part of her efforts, which are more typical of a medical drama than of a forensic thriller, include being exposed to the victims' blood and internal organs in an effort to stop the hemorrhage. This performance of CPR is possible only through the southern gothic tradition that allows for "the odd, the eccentric, and the physically or sexually atypical" (Downey 365): "Sara tried again, gagging as blood coughed up into her mouth. She spat several times to clear her mouth prepared to continue, but it was too late ... A trickle of urine came from between her legs" (Slaughter 13). It is necessary here to highlight that through the release of urine by a dead body is not something atypical, its representation in mainstream fiction is. Though her predecessors Cornwell and Reichs did in fact great work in rehabilitating the representation of dead bodies in forensic thrillers, they stayed away from these details. Hence, there is plenty of space in regional forensic thrillers for the abject (Yaeger 228), for that part of society that lacks representation and that organically emerges linked to the area's own misrepresentations in mainstream culture.

\section{Conclusions}

The US regional forensic thriller has become one of the most successful crime fiction subgenres in $21^{\text {st }}$-century crime fiction. Their portrayal of regions of the USA that had been traditionally stereotyped or misrepresented is one of these novels' strengths as they challenge a homogeneous representation of the country. Even though the regional forensic thriller can be located in any region, southern settings seem to be preferred by reading audiences as they offer a more complex look at southern culture. The South's cultural richness - made patent in the elements borrowed from the Southern Gothic tradition - allows more realistic representations of crime scenes and autopsy. Despite the specificity of southern culture, regional forensic thrillers have been a success outside the US: Slaughter's works have been translated into more than twenty-five languages (Slaughter Personal Website).

More importantly, regional forensic thrillers consider the author's lived experience and they infuse it with value by recognizing the complexity of southern culture. Even though forensic thrillers have traditionally been inspired by the writer's professional lives, the fact that these regional texts focus on the everyday 
life and dominant discourses at play in the construction of culture is a tool of representation that challenges the assumptions and stereotypes that have shaped the understanding of the South by outsiders. The focus on the tension between tradition and innovation is present in the combination of traditional lifestyle choices (the power of religion to construct the dominant discourse) and the consideration of forensic science as the only legitimate way to produce truth and restore the status quo.

Hence, it is necessary to reconsider the cultural impact of the regional forensic thriller in mainstream culture and in the global construction of southern culture in mainstream popular products. These texts highlight the diversity of the US as a country and they describe the delicate balance that needs to be found between tradition and innovation both in literature and in everyday life so as to make the past accountable while accepting social change and innovation in an area as historically and culturally complex as the South.

\section{Works Cited}

Avanzas Álvarez, Elena. Murder She Re/Wrote: The Evolution of the Forensic Doctor in US Forensic Thrillers. PhD Thesis. University of Oviedo, 2018.

Bertens Johannes Willem, and Theo D'haen. Contemporary American Crime Fiction. USA: Palgrave, 2001. Print.

Cohen, Jonathan. "Defining identification: a theoretical look at the identification of audiences with media characters." Mass Communication \& Society 4(3): 24564, 2001.

Cornwell, Patricia. The Kay Scarpetta Collection. Volume I. Postmortem and Body of Evidence. USA: Scribner, [1990] 2001. Print.

Curie, Gregory. Narratives and Narrators. A Philosophy of Stories. Oxford: Oxford University Press, 2010. Print.

Davies, David. "Fictionality, Fictive Utterance, and the Assertive Author." Mimesis: Metaphysics, Cognition, Pragmatics, 2012. 61-85.

Donahue, Ann, Carol Mendelsohn, and Anthony E. Zuiker, creators. 2015. CSI. Entertainment One, 2000-2015.

Downey, Dara. "The Gothic and the Grotesque in the Novels of Carson McCullers." The Palgrave Handbook of the Southern Gothic. Ed. Susan Castillo and Charles L. Crow. Palgrave MacMillan, 2017. 365-379. Print.

Flynn, Gillian. Sharp Objects. Random House, 2007. Print.

Foucault, Michele. The History of Sexuality: Volume I, translated by Robert Hurley. Random House, 1978. Print.

Friend, Stacie. "Believing in Stories." Aesthetics and the Sciences of the Mind. Ed. Greg Curie, Matthew Kieran, Aaron Meskin and Jon Robson. Oxford: Oxford University Press, 2014. 224-247. Print.

. "Fiction as Genre." Proceedings of the Aristotelian Society, vol. 99, no 179, 2012, https://doi.org/10.1111/j.1467-9264.2012.00331.x Accessed: 25th July 2018 .

. "Imagining Fact and Fiction." New Waves in Aesthetics. Ed. Kathleen Stock and 
Katherine Thomson-Jones. Palgrave, 2008. 150-169. Print.

. "Narrating the Truth (More or Less)." Knowing Art: Essays on Aesthetics and

Epistemology. Ed. M. Kieran and D. McIver Lopes, Springer, 2006. 35-49.

Print.

García-Carpintero, Manuel. "To Tell What Happened as Invention: Literature and Philosophy on Learning from Fiction." Literary Studies and the Philosophy of Literature: New Interdisciplinary Directions. Ed. Aandrea Slleri and Philip Graydon. Palgrave Macmillan, 2016. 123-147. Print.

Gerritsen, Tess. The Surgeon. UK: Transworld Books, [2001] 2010. Print. . The Apprentice. UK: Transworld Books, [2002] 2010. Print.

. The Surgeon. UK: Transworld Books, [2001] 2010. Print.

. The Sinner. UK: Transworld Books, [2003] 2010. Print.

Knight, Stephen. Crime Fiction 1800-2000. Detection, Death, Diversity. Palgrave MacMillan, 2004. Print.

Martin, Denise. "Devil's Nests and Beer-Can Men: The Origins of 13 True Detective Set Pieces." New York Media. 2014, http://www.vulture.com/consent. html?redirect_uri=\%2F2014\%2F03\%2Ftrue-detective-alex-digerlando-setdesign-props-interview.html\%3Fvia\%3Dgdpr-consent\&redirect_host=www. vulture.com\&orig_qs $=$. Accessed: 5th July 2018.

Munt, Sally. Murder by the Book? Feminism and the Crime Novel. New York: Routledge, 1994. Print.

Pizzolatto, Nic, creator. True Detective (First season). HBO, 2014.

Reichs, Kathy. Dèja Dead. UK: Arrow Books, [1997] 2011. Print.

Said, Edward. Orientalism: Western Conceptions of the Orient. London: Penguin, [1978] 2002. Print.

Silverman, Kenneth. Edgar A. Poe: Mournful and Never-Ending Remembrance. New York: Harper Perennial, 1991. Print.

Slaughter, Karin. Blindsighted. UK: Arrow Books, [2001] 2011. Print. . Personal Website, 2018, http://www.karinslaughter.com/languages/. Accessed: 28th July 2018.

Walton, Priscilla L., and Manina Jones. Detective Agency: Women Rewriting the Hard Boiled Tradition. California: University of California Press, 1999. Print.

Yaeger, Patricia. Dirt and Desire: Reconstructing Southern Women's Writing. USA: Chicago University Press, 2000. Print. 